\title{
Determinants of Teff Producers Market Orientation in Horo Buluk District of Horo Guduru Wollega Zone, Ethiopia
}

\author{
Seid ${ }^{1}$ Hassen \\ Department of Agricultural Economics, Wollega University P. O. Box 38, Ethiopia \\ Bacha $^{2}$ Gebissa \\ Department of Agricultural Economics, Wollega University P. O. Box 38, Ethiopia
}

\begin{abstract}
In Ethiopia, teff is an important cereal crop, particularly in Horo Buluk district. It is source of food and cash income for majority of the smallholder farmers. The study was aimed to analyze factors affecting the market orientation of teff producers in Horo Buluk district. The study used both primary and secondary data. Total of 190 farmers were randomly selected in the district. Both descriptive statistics and econometric models were used. Tobit model was used to identify determinants of market orientation. Results of the descriptive statistics indicated that the average market orientation level of teff producers in the district was $20.59 \%$ from which $32.63 \%$ of sample households were subsistent, $20 \%$ of them were less oriented, $45.78 \%$ of them were moderate market oriented and only $1.57 \%$ were market oriented farmers. The result of Tobit regression model indicated that educational level, perception on lagged market price and number of oxen owned significantly and positively affected market orientation of teff producers while Family size was related to market orientation negatively. Farmers should have to use modern technologies, improved seeds, and access to credit. Furthermore there is a need to strengthen the rural education system, strengthen the family planning program to increase teff market orientation.
\end{abstract}

Key words: Smallholders, market orientation, Tobit, Teff, Horo Buluk

DOI: $10.7176 / \mathrm{EJBM} / 12-13-06$

Publication date:May $31^{\text {st }} 2020$

\section{INTRODUCTION}

Agriculture continues to dominate the national economy of Ethiopia, contributing 36.3\% for GDP and over 70\% of exports earning (UNDP, 2018). It also generates employment for $73 \%$ of the total population and supplies $70 \%$ of the raw-material requirements of local industries (UNDP, 2016). In Ethiopia 95\% of the total area under agriculture is cultivated by smallholder farmers and contributes to $90 \%$ of the total agricultural output indicating the dominant contribution of smallholder farmers to the overall agricultural production (MoARD, 2010; Gebreslassie and Bekele, 2012). Ethiopia has a comfortable land to produce both cash and food crops. Cereal production occupies the major share of agricultural production in Ethiopia of which teff, maize, sorghum and wheat are highly produced. Teff is the most important cereals and largely cultivated in Ethiopia .It has high share of cultivated land followed by maize sorghum and wheat respectively (CSA, 2018). Teff is the second most important cash crop next to coffee generating almost 500 million USD incomes per year for local farmers (Minten et al., 2013) .It is the second largest cereal crop produced after maize (CSA, 2018). Considering the value of the crop most farmers utilize more land to produce teff than other crops.

Teff had 23.855 percent share of cultivated land among cereals. In 2017/18 about 3,023,283.50 hectare land allocated for teff production with the productivity of 17.48 quintal per hectare was reported globally in Ethiopia. $1,443,847.96$ hectare is allocated in oromia region and also in average 17.88 quintal per hectare is harvested (CSA, 2018). In Horo Guduru Wollega Zone 51,348.5 land was allocated and average productivity per hectare was 17.7 quintal. 5321 hectare is allocated in horo buluk district with the productivity of 19.62(Archives of HGWZOARD, 2019).However different factors affect teff market orientation; most farmers allocate more land for the crop in the study area. Price fluctuations, lack of market information and shortage of land are among the factor highly affecting teff market orientation. teff tooks its lion share in relation to other cereal.

\section{MATERIAL AND METHOD}

\section{Description of the study area}

The study was conducted in Horo Buluk district. Horo Buluk district is located Horo Guduru Wollega Zone in Oromia National Regional State about $341 \mathrm{~km}$ away from Addis Ababa. Horo Buluk district has an area of about $767.07 \mathrm{~km} 2$. Astronomically, the location of the district is between $11^{\circ} 09^{\prime} 60.00^{\prime \prime} \mathrm{N} 37^{\circ} 00^{\prime} 0.00^{\prime \prime} \mathrm{E}$. According to Oromia population projection made based on 2007 Population and Housing Census result, the total population of Horo Buluk district is about 52,998 out of which $49 \%$ are male and $51 \%$ are female $2017 / 18$. Abay coman district borders it to the east; Abe dongoro district borders it to the west, Jardaga jarte and Horo district border to the north and south respectively. The administrative center of the district is Sekela town. 


\section{Sampling Procedure and Sample Size}

A two stage sampling technique was employed to select sample respondents. Teff producer farmer households were the target population of the study. In the first stage four teff producing kebeles from eleven rural kebeles of district were selected randomly. In second stage from the selected kebeles, teff Producer farm households were identified in collaboration with development agents. In this stage a total of 190 teff producer farm households had selected randomly from the selected sample kebeles by using simple random sampling technique. The maximum numbers of respondents were determined by using a formula developed by Yamane (1967). To determine the required sample size, $7 \%$ level of precision is used.

$\mathrm{n}=\frac{\mathrm{N}}{1+\mathrm{N}(\mathrm{e})^{2}} \quad=\frac{2714}{1+2714(0.07)^{2}}=189.8088$ 190

$\mathrm{n}=$ is the sample size

$N=$ number of households' from which the sample was drawn.

$e=$ is the error term which was $7 \%(0.07)$.

\section{Data Types, Sources and Methods of Data Collection}

The study engaged both quantitative and qualitative types of data collected from both primary and secondary sources. The primary data from farmers was gathered focusing on factors affecting the market orientation, proportion of teff produce.

\section{Methods of Data Analysis}

Two types of data analysis, namely descriptive statistics and econometric models were used to analyze the data collected from the households.

\section{Descriptive statistics}

Descriptive method of data analysis like percentages, frequency, means and standard deviations was employed in the process of comparing household's market orientation status. Market orientation index of households was calculated for each household in the sample based on the resource a farmer allocates for teff production following (Gebremedhin and Jaleta (2012) and woldeyohanis et al. (2017)). Based on the proportion of total amount sold to total production at farming system level, a crop specific marketability index $\left(\alpha_{\mathrm{K}}\right)$ is computed for teff produced at farm level system as follows:

$\mathrm{TM}=\frac{\text { gross value } \text { of teff sold by individual farmers/year }}{\text { total value of teffproduced by individual farmers }}$

Where, TMi refers to teff marketability index for individual farmer in 2017/2018 production year.

$\boldsymbol{\alpha}_{\mathbf{K}}=\frac{\sum_{\mathbf{i}=1}^{\mathrm{N}} \mathbf{S}_{\mathbf{k i}}}{\sum_{\mathbf{i}=\mathbf{1}}^{\mathrm{N}} \mathbf{Q}_{\mathbf{k i}}}, \mathbf{Q}_{\mathbf{k i}} \geq \mathbf{S}_{\mathbf{k i}}$ and $0 \leq \boldsymbol{\alpha}_{\mathbf{K}} \leq 1$

Where $\alpha_{\mathrm{K}}$ is the proportion of teff sold (Ski) to the total amount of teff produced (Qki) aggregated over the total sample of households in a farming system. $\left(\alpha_{\mathrm{K}}\right)$ has value between 0 and 1.A value of zero would signify a totally subsistence level of production and the closer the index is to 100 , the higher the market orientation in production. After the crop, specific marketability index is calculated, household's market orientation index in land allocation (MOIi) will be computed from the land allocation pattern of the household weighted by the marketability index of the crop $\left(\alpha_{\mathrm{K}}\right)$ derived from Equ.4

$\mathrm{MOI}_{\mathrm{i}}=\frac{\sum_{\mathrm{k}=1}^{\mathrm{k}} \alpha_{\mathrm{KL}_{\mathrm{ik}}}}{\mathrm{L}_{\mathrm{i}}^{\mathrm{T}}} ; \mathrm{L}_{\mathrm{i}}^{\mathrm{T}}>0$ and $0<\mathrm{MOI}_{\mathrm{i}} \leq 1$

Where MOIi is market orientation index of farmer $\mathrm{i}, \mathrm{L}_{\mathrm{ki}}$ is amount of land allocated for teff in hectare, and $\mathrm{L}_{\mathrm{i}}^{\mathrm{T}}$ is the total crop land operated by farmer measured in hectare.

3.4.2. Econometric Model Specification

Given the observed dependent variable market orientation index (yi), the Tobit model is specified as:

$\mathrm{y}_{\mathrm{i}}=\beta_{\mathrm{i}}^{\prime} \mathrm{x}_{\mathrm{i}}+\mathcal{E}$

$\mathrm{y}_{\mathrm{i}}=\left\{\begin{array}{l}0 \text { if } \mathrm{yi} * \leq 0 \\ \mathrm{y} * \text { if } \quad 0<\mathrm{y} * \leq 1 \ldots \ldots \ldots \ldots\end{array}\right.$ 
$\mathrm{Xi}=$ is vector of independent variables, which includes factors affecting intensity of market orientation; $\beta_{\mathrm{i}}$ is vector of unknown parameters to be estimated; $\varepsilon$ is a disturbance term assumed to be normally distributed with zero mean and constant variance $\sigma 2$.

\section{RESULTS AND DISCUSSION}

\section{Description of market orientation}

The result showed that among the producers by the sample farm households $128(67.36 \%)$ of them were market oriented and the rest $62(32.63 \%)$ not. The degree of teff market orientation $20.59 \%$.

The marketability indexes of teff show that nearly $44.45 \%$ of the crop was sold on average which indicating that the crop was moderately marketed in the study area. The minimum and maximum marketability index of teff is 0 and 0.97 respectively.

As the study of Woldeyohanis et al., (2017) on malty barley, smallholders' level of market orientation index is grouped into three categories: Less market oriented (up to 25\%), semi-market oriented (between 25\% and 50\%) and market oriented farmers (for more than 50\%). This category is because of malty barley is commercial crop. Considering the issue market orientation level is categorizer into four groups as follow in the table 1.

Table 1 level of market orientation of teff producer's respondents in 2017/18 production year

\begin{tabular}{|l|l|l|l|}
\hline Extent of market orientation & Orientation Level & frequency & percentage \\
\hline Subsistent & $0 \%$ & 62 & 32.63 \\
\hline Less market oriented & Between 0 and 25\% & 38 & 20 \\
\hline Moderate & Between 25\% and 50\% & 87 & 45.78 \\
\hline Oriented & Greater than 50\% & 3 & 1.57 \\
\hline Average & $20.6 \%$ & 190 & 100 \\
\hline
\end{tabular}

Source: Own survey (2019)

Econometric Results

Family size: Household size measured as adult equivalent was found to have negative and significant influence on teff market orientation at 5\% significance level. The marginal effect shows that as the member of household increased by one adult equivalent decreases the probability of market orientation by $0.81 \%$ while it decreases the intensity of teff market orientation by $0.97 \%$ and the whole by $1 \%$. This result is expected because households with more household member tend to consume more of teff output produced and less land is allocated for sales. This result is in line with Woldeyohanis et al.,(2017).

Education level: Education of household head is positively associated with market orientation of teff producers at $1 \%$ significance level. The marginal effect indicated that as the level of formal education of the household head increased by one grade, increase the probability of market orientation by $2.68 \%$ whereas it increases the intensity of teff market orientation by $3.21 \%$ and whole by $3.6 \%$.This indicates that attending formal education improves the productivity and amount of teff marketed by adopting improved agricultural technologies. This study is in line with a finding of woldeyohanis et al. (2017).

Perception on lagged market price: Perception on lagged market price affected teff market orientation positively and significantly $1 \%$ significance level. The marginal effect shows that when the price of teff is high market orientation probability of households increase by $5.2 \%$, intensity increase by $4.9 \%$ and whole increment was by $5.6 \%$. This result implies that price has a big power to change to decision of households. This study is in line with Getahun (2018).

Oxen ownership oxen ownership positively determines the households' market orientation at $10 \%$ significance level. The marginal effect shows one ox addition would increase the probability of market orientation by $0.71 \%$ whereas it increases the intensity of teff market orientation by $0.86 \%$.and the whole by $0.96 \%$. The result indicated that farmers who have more oxen can farm more land whether in form of share or rent which increases production and enable market orientation. The result is in line with Tefera (2014).

Table 1 Determinants of Teff Market Orientation

\begin{tabular}{lllllll}
\hline Market orientation index & Coef. & Std. Err. & $\mathrm{P}>\mathrm{t}$ & $\operatorname{Pr}(\mathrm{y}>0)$ & $\mathrm{E}(\mathrm{y} \mid \mathrm{y}>0)$ & $\mathrm{E}(\mathrm{y} * \mid \mathrm{y}>0$ \\
\hline Sex & .0136001 & .01959 & 0.488 & .010713 & .0116337 & .0131559 \\
Age & .0017712 & .001265 & 0.163 & .001278 & .0015323 & .0017192 \\
Family size & $-.011322^{* *}$ & .004658 & 0.016 & -.008174 & .0097955 & .0109905 \\
Cooperative member & .0150242 & .0157981 & 0.343 & .010650 & .0130284 & .0145921 \\
Education level & $.0371468^{* * *}$ & .0039058 & 0.000 & .026816 & .0321356 & .0360561 \\
Non-farm income & .0010941 & .0010471 & 0.297 & .000789 & .0009465 & .001062 \\
Perception on lagged price & $.058870^{* * *}$ & .0179759 & 0.001 & .052996 & .0494977 & .056565 \\
Distance from market & -.000045 & .000572 & 0.936 & -.00003 & .0000396 & .0000444 \\
Number of oxen & $.009941^{*}$ & .0056938 & 0.083 & .007176 & .0086001 & .0096493 \\
Livestock excluding oxen & .0005531 & .0013035 & 0.672 & .000399 & .0004785 & .0005368 \\
\hline
\end{tabular}




\begin{tabular}{lllllll}
\hline Market orientation index & Coef. & Std. Err. & $\mathrm{P}>\mathrm{t}$ & $\operatorname{Pr}(\mathrm{y}>0)$ & $\mathrm{E}(\mathrm{y} \mid \mathrm{y}>0)$ & $\mathrm{E}(\mathrm{y} * \mid \mathrm{y}>0$ \\
\hline Number of extension visit & .000564 & .0022799 & 0.805 & .000407 & .000488 & .0005475 \\
Credit use & .0028022 & .0153823 & 0.856 & .002024 & .0024239 & .0027198 \\
Chemical fertilizer used & .0001142 & .0001224 & 0.352 & .000082 & .0000988 & .0001108 \\
cons & -.137916 & .0933994 & & & & \\
/sigma & .0925832 & .0060949 & & & & \\
Number of observations $=190$ Prob $>$ chi2 $=$ & 0.0000 & & & \\
Left-censored observation $=62$ & Log likelihood $=89.939165$ & & \\
Uncensored observation $=128$
\end{tabular}

Source: model output (2019)

Note: $* * *, * *$ and $*$ shows $1 \%, 5 \%$ and $10 \%$ significance level respectively

$\operatorname{Pr}(y>0), E(y \mid y>0)$ and $E(y * \mid y>0$ indicates change in probability of market orientation, change in intensity of market orientation and change in whole respectively.

\section{CONCLUSIONS AND RECOMMENDATIONS}

In Horo Buluk district however teff is considered as both cash and food crop; about $20.59 \%$ only was market oriented .From the study it was found that different demographic, socioeconomic and institutional factors inhibited most of the farmers' teff Market orientation. In order to help design appropriate intervention strategies to improve the smallholder farmers' market orientation of teff production in the study area; provision of adequate and effective formal and informal education to the rural farming households and to the study area in particular enhances households 'market orientation; government should intervene through provision of rural employment opportunities is essential to reduce high dependence on farm output and to increase the proportion outputs sold; long term credit are required from locally existing microfinance institutions in improving number of oxen ownership for smallholder farmers since they used it as means of a traction power and threshing that enhances market orientation of teff producers. Another huge effort of replacing oxen power by tractor should take place by technology transfer concerns of body the government that simplifies farming activity; train farmers about contract farming and time sell of produces, they feel confident on price they receive from production of teff and will take advantage of price fluctuation thereby increase their market orientation of teff.

\section{REFERENCES}

1. CSA (Central Statistical Agency). 2018 Agricultural Sample Survey 2017/2018 (2010 E.C): Report on area and production of major crops, volume-I. Addis Ababa, Ethiopia.

2. Gebremedhin, B. and Jaleta, M., 2012. Market orientation and market participation of smallholders in Ethiopia: Implications for commercial transformation Paper presented at International Association of Agricultural Economists (IAAE) Triennial Conference, Foz do Lguacu, Brazil.

3. Getahun A, 2018, Determinants of commercialization and market outlet choices of tef: the case of smallholder farmers in dendi district of oromia, central Ethiopia, haramay university, Ethiopia

4. Minten, B., Tamru, S., Engida, E. and Kuma, T., 2013. Ethiopia's value chains on the move: The case of teff. Ethiopia Strategy Support Program II Working Paper, 52, pp.1-26.

5. MoARD (Ministry of Agriculture and Rural Development), 2010. Ethiopia's Agricultural and Sector Policy and Investment Framework (PIF): 2010-2020, Addis Ababa, Ethiopia.

6. Tefera, T., 2014. Determinants of smallholder pulse producers market orientation in Southern Ethiopia. Asian Journal of Business Management, 6(2); 97-103.the time period 2005-2012. The time

7. Tobin, J. 1958. Estimation of Relatisonships for Limited Dependent Variables. Econometrica, 26(1): 24-36.

8. UNDP (United Nation Development Programme), 2018. Ethiopia's progress towards eradicating Poverty. Paper to be presented to the inter-agency group meeting on the implementation of the third United Nations decade for the eradication of poverty $(2018$ - 2027)Ababa, Ethiopia.

9. Yamane $\mathrm{T}$ (1967). Statistics, an Introductory Analysis, 2nd Ed. New York: Harper and Row. www.sciepub.com/reference/180098 